\title{
A New Antigen System Expressed in Human Endothelial Cells
}

\author{
J. Roberto Moraes and Peter Stastny
} From the Department of Internal Medicine, Transplantation Immunology Section, The University
of Texas Health Science Center at Dallas, Dallas, Texas 75235

A B S T R A C T Kidney transplant recipients were previously found to have antibodies that reacted with cells isolated from the endothelium of umbilical cord veins and which were not cytotoxic for lymphocytes from the same donors. Results of the present experiments indicate that endothelial $(\mathrm{E})$ antigens are different from previously known HLA antigens and also from Ia-like antigens of bone marrow-derived (B) lymphocytes. Attempts to absorb $\mathrm{E}$ antibodies with lymphocytes from E-positive donors failed in most cases. Antigen redistribution experiments showed that $\mathrm{E}$ antigens were located in separate molecules from the products of HLA-A, B, and C. Thus, E cells treated with E antibody became resistant to lysis by the antibody used, but remained susceptible to the effects of typing sera for alleles of HLA-A, B, and C. Antibodies to E cells were also cytotoxic for blood monocytes. Moreover, monocytes were able to absorb E-antibody reactions, indicating that similar antigens were expressed in both cells. E antibodies did not react with $B$ lymphocytes isolated from peripheral blood. In that regard $\mathrm{E}$ antibodies were different from antibodies to human Ialike antigens which reacted with $\mathrm{E}$ cells, monocytes, and isolated B lymphocytes. Thus it appears that E antigens constitute a system of human alloantigens which has not been previously identified. The possibility that these antigens play a role in kidney allograft rejection should now be investigated since matching can be performed using monocytes isolated from the blood of recipients and donors.

\section{INTRODUCTION}

The HLA region of the sixth human chromosome (1) contains, in addition to the main histocompatibility

Dr. Moraes is the recipient of fellowships from the Pan American Health Organization and Ministerio da Educacao e Cultura (CAPES), Brazil.

Received for publication 19 October 1976 and in revised form 18 April 1977. loci HLA-A, HLA-B, and HLA-C, the more recently defined HLA-D locus which controls strong stimulation in mixed lymphocyte cultures (2) and others such as loci for Ia-like antigens expressed preferentially in bone marrow-derived (B) lymphocytes (3-5) and for complement components (6-8) produced by macrophages (9). By analogy with homologous chromosomal regions in other species, the HLA region probably also controls cellular interactions and participates in the regulation of the immune response (10-12). The success of kidney allografts from HLA-matched siblings, in immunosuppressed hosts, is evidence that the HLA region is the main barrier to human kidney transplantation. Compared to chromosome matching as performed when donors are sought in families, HLAantigen matching with lymphocytes as commonly performed for cadaveric kidney transplantation, has been less effective in predicting the outcome of unrelated allografts (13). Since matching either by serologic methods or by mixed lymphocyte cultures has usually been performed with lymphocytes, and since the products of some HLA loci are not expressed equally in all cells, it is appropriate to ask whether the kidney might express antigens important for transplantation which are not detected in lymphocytes of peripheral blood (14). It is known that some transplant recipients do not develop lymphocytotoxic antibodies even after allograft rejection (15), and administration of lymphocytes, in the form of random blood transfusions before transplantation, appears to have no adverse effect on survival of subsequent kidney allografts (16).

Vascular endothelium is rich in alloantigens which can be detected serologically (17) and in mixed lymphocyte cultures (18). It constitutes a large surface of contact over which host blood flows into the grafted organ and is likely to be a source of antigenic stimulation. Vascular lesions are known to play a predominant role in kidney allograft failure (19).

In a previous report, sera from transplant recipients were found to contain antibodies against endothelial 
cells which did not react with lymphocytes from the same donors. The results of the present experiments have shown that endothelial $(\mathrm{E})^{1}$ antigens, detected with such antibodies, are different from the alleles of HLA-A, B, and C, that similar antigenic structures are expressed in adherent mononuclear cells from the blood, and that these $\mathrm{E}$ antigens are distinct from the human Ia-like antigens which are found in B cells (4). The results indicate that $\mathrm{E}$ antigens and Ia-like antigens, as well as the antigens of HLA-A, B, and C, are found in E cells.

\section{METHODS}

E cells. Umbilical cords separated from the placenta at delivery were placed in cold phosphate-buffered saline (PBS) and processed within $3 \mathrm{~h}$. E cells were detached from umbilical cord veins after brief treatment with trypsin (20). The veins were cannulated at each end and washed with PBS to remove retained blood (Fig. 1). The vessels were filled with $0.25 \%$ trypsin solution (Grand Island Biological Co., Grand Island, N. Y.), incubated for 15-20 min at $37^{\circ} \mathrm{C}$, and then flushed with additional PBS. The $\mathrm{E}$ cells were received in siliconized tubes containing $8 \mathrm{ml}$ of medium RPMI 1640 with $20 \%$ pooled normal human serum and washed twice using $20 \mathrm{ml}$ of the same medium. Each preparation yielded $0.5-3 \times 10^{6}$ viable $E$ cells.

Lymphocytes. A sample of cord blood was obtained from each newborn donor to prepare lymphocyte suspensions to match the preparations of $E$ cells. The blood was diluted 1:3 with PBS and placed on Ficoll-Hypaque (Lymphoprep, Nyegaard, Oslo, Norway) for separation of the mononuclear cells $(21)$

Monocytes. Mononuclear cells obtained from FicollHypaque preparations of cord blood were separated into adherent and nonadherent cell populations by incubation in plastic Petri dishes. 60-80 million mononuclear cells were suspended in $6 \mathrm{ml}$ RPMI 1640 with $20 \%$ pooled human serum and cultured in 10-cm diameter plastic dishes (Falcon Plastics, Division of BioQuest, Oxnard, Calif.) for $2 \mathrm{~h}$ at $37^{\circ} \mathrm{C}$ in a humid atmosphere containing $5 \% \mathrm{CO}_{2}, 95 \%$ air. Nonadherent cells were removed by several washes with culture medium, checking for completeness with an inverted phase-contrast microscope. When only adherent cells remained, they were released from the dishes using a rubber policeman, collected in conical centrifuge tubes containing RPMI 1640 with $20 \%$ pooled human serum, and then washed once. Adherent cells obtained in this manner were 75-95\% viable by trypan blue exclusion. Morphologically they had the appearance of monocytes; less than 15\% looked like small or medium-sized lymphocytes. When incubated with latex particles, $70-80 \%$ of the cells were observed to be phagocytic. Using euchrysine staining (22), 70-80\% of the cells adhering to petri dishes had red fluorescence in the cytoplasm and bean-shaped nuclei characteristic of monocytes.

Thymus-derived $(T)$ and B lymphocytes. Cells obtained after Ficoll-Hypaque flotation of cord blood were washed once, adjusted to a concentration of $2 \times 10^{6} / \mathrm{ml}$ in RPMI 1640 containing $1 \%$ bovine serum albumin, mixed with an equal volume of $0.5 \%$ neuraminidase-treated sheep erythrocytes (23), incubated at $37^{\circ} \mathrm{C}$ for $15 \mathrm{~min}$ with intermittent shaking, centrifuged for $3 \mathrm{~min}$ at $200 \mathrm{~g}$, and then stored at $4^{\circ} \mathrm{C}$ overnight. The following day, pellets were resuspended gently, underlayered with Ficoll-Hypaque, and centrifuged at $400 \mathrm{~g}$ for $30 \mathrm{~min}$ to obtain $\mathrm{B}$ cells at the interphase.

${ }^{1}$ Abbreviations used in this paper: E, endothelial; PBS, phosphate-buffered saline.

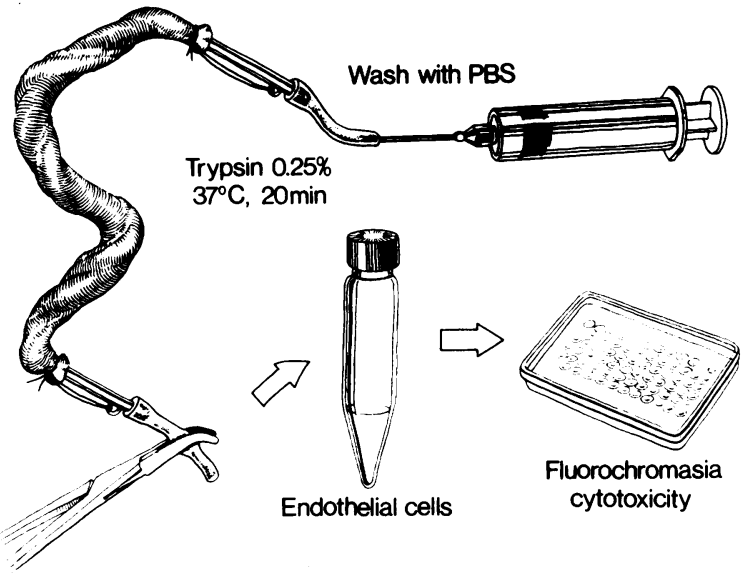

Figure 1 Preparation of E cells from umbilical cord veins. The veins were cannulated at each end as shown. Clamps placed on short rubber tubing were used to retain trypsin solution during incubation. For additional details see text.

To obtain $\mathrm{T}$ cells, the sheep erythrocytes in the rosettes sedimented under the Ficoll-Hypaque were lysed by brief incubation with Tris-buffered ammonium chloride at $37^{\circ} \mathrm{C}(24)$, followed by washing.

Cytotoxicity tests. A microcytotoxicity method was used. Sera to be tested were dispensed in $1-\mu l$ amounts into plastic microtest trays (Cooke Laboratory Products Div., Dynatech Laboratories Inc., Alexandria, Va.) under droplets of mineral oil and frozen for future use. The reading of cytotoxic reactions was performed by the fluorochromatic assay as described by Bodmer and co-workers (25), with some modifications. In this procedure, fluorescein diacetate (ICN Nutritional Biochemicals Div., International Chemical \& Nuclear Corp., Cleveland, Ohio) was dissolved in acetone, $5 \mathrm{mg} / \mathrm{ml}$, and stored frozen in multiple small portions. Just before use, $0.1 \mathrm{ml}$ of this solution was diluted 1:100 with RPMI 1640 and $0.1 \mathrm{ml}$ of this working solution was added to each milliliter of cell suspension. The cells were incubated with fluorescein at room temperature for $15 \mathrm{~min}$, washed in RPMI 1640 at $4^{\circ} \mathrm{C}$, and resuspended in Hanks' balanced salt solution with $3 \%$ bovine serum albumin. The labeled cells were then adjusted to a concentration of $2 \times 10^{6} / \mathrm{ml}$, and $1 \mu \mathrm{l}$ (approximately 2,000 cells) was added to each reaction mixture. The complement used was known from preliminary tests not to be toxic for $\mathrm{E}$ cells. Incubation with complement was allowed to continue for $60 \mathrm{~min}$ at room temperature. The trays were then refrigerated and read as soon as possible. Readings were performed using a Leitz fluorescence microscope equipped with a dry darkfield condenser and a $10 \times$ objective (E. Leitz, Rockleigh, N. J.). Live cells in control preparations showed bright green fluorescence. A decrease of $50 \%$ was required for a positive score. If more than $80 \%$ of the cells were killed, a reaction was scored strong positive. Cytotoxicity tests with monocytes were performed similarly. Tests with B lymphocytes were incubated with complement for $2 h$ and readings were made using eosin staining instead of fluorochromasia.

HLA-typing. Antisera used to identify the antigens of HLA-A, B, and C were derived from the local pregnancy serum screening program, or obtained from the National Institutes of Health serum bank and from other investigators. With these reagents it was possible to identify all the World Health Organization and the International Union of Immunological Societies' established alleles (1), however, certain sera which were in short supply, particularly those for HLA-CW1 through CW5, were not used in the typing of 
all the donors. In the antigen redistribution experiments, sera of the 6th International Histocompatibility Workshop were used. The typing procedure employed in these tests was the same cytotoxicity method described above.

Antibodies against human Ia-like antigens. Pregnancy sera, reacting with isolated peripheral blood B lymphocytes and not with $\mathrm{T}$ lymphocytes from the same donors, were selected from a group of 200 sera found to be negative or only weakly reactive in screening with whole lymphocyte preparations from 50 persons. Two of the six sera selected for the present experiments had previously been absorbed with platelets to remove cytotoxicity for $\mathrm{T}$ lymphocytes. A rabbit serum prepared by immunization with isolated Ia antigen from cultured human B lymphocytes was obtained from Dr. Walter Bodmer, Genetics Laboratory, Department of Biochemistry, University of Oxford, England. These sera were known to react with $B$ lymphocytes and monocytes from many donors and their reactions were not abolished by stripping with anti-B2 microglobulin as described by Jones and co-workers (4).

Antiserum against human T-lymphocyte antigens. A rabbit serum specific for human $T$ lymphocytes (26) was obtained from a commercial supplier (Institut Merieux, Lyon, France). The serum was produced in rabbits by immunization with human $\mathrm{T}$ lymphocytes and absorbed with cultured B-lymphoblastoid cells and with adherent mononuclear cells. At a dilution of 1:32 this serum reacted with $80-100 \%$ of isolated peripheral blood $\mathrm{T}$ lymphocytes and was negative with B lymphocytes, monocytes, and E cells.

Absorption experiments. Unlabeled cells were added to the serum droplets and preincubated before performing a test with fluorescinated cells in the usual manner. In such absorption experiments, 30,000-60,000 E cells, 100,000200,000 lymphocytes or 60,000 monocytes were added to 1 $\mu l$ of antiserum and incubated for $2 \mathrm{~h}$ at $22^{\circ} \mathrm{C}$ before performing a cytotoxicity test as described above.

Antigen redistribution tests by the resistance-induction method. The procedure to test for the molecular independence of antigens on the surface of $E$ cells was based on development of specific resistance to antibody-mediated lysis as described by Bernoco and co-workers (27) and more recently by Hauptfeld and co-workers (28). Briefly, E cells at a concentration of $2 \times 10^{6} / \mathrm{ml}$ were incubated with an equal volume of serum containing specific $E$ antibodies for $2 \mathrm{~h}$ at room temperature, washed twice in cold RPMI 1640, and then resuspended to the original concentration. The cells were then incubated with an equal volume of rabbit antis human immunoglobulin at $0^{\circ} \mathrm{C}$ for $30 \mathrm{~min}$ and washed twice in cold RPMI 1640. Then the cells were incubated for $30 \mathrm{~min}$ at $37^{\circ} \mathrm{C}$, promptly cooled to room temperature, and labeled with fluorescein diacetate for use in cytotoxicity testing. The interpretation of these experiments depends on a control preparation which was treated with normal human $\mathrm{AB}$ serum instead of serum containing antibodies and then carried through all the steps of the procedure.

\section{RESULTS}

Absorption of $E$ antibodies with peripheral blood lymphocytes. A number of sera known to react only with $\mathrm{E}$ cells were tested for cytotoxicity to $\mathrm{E}$ cells before and after absorption with either $\mathrm{E}$ cells or lymphocytes (Table I). In 20 experiments, absorption with reactive $E$ cells removed the cytotoxicity every time. Sera absorbed with matching lymphocytes remained cytotoxic for the corresponding E cells in 28 of 35 experiments. Serum antibodies reacting with lymphocytes were absorbed by both E cells or lympho- cytes in all the experiments (Table I). These results suggested that $\mathrm{E}$ antigens were absent or present in insufficient quantity in most peripheral blood lymphocyte preparations.

Molecular independence of $E$ antigens. HLA typing of $E$ cells and lymphocytes from the same donors for the antigens of the HLA-A, B, and C series showed good agreement in most cases. Each antigen was defined by the concordant reactions of several typing sera of the Sixth International Histocompatibility Workshop. The workshop serum numbers which identify the reagents used are given in the footnote to Table II. The cytotoxic reactions were unimpaired when the $\mathrm{E}$ cells were pretreated with normal human $\mathrm{AB}$ serum followed by rabbit anti-human immunoglobulin and processed through the various incubation and washing steps required for the resistance-induction procedure. In each of the experiments shown in Table II, a different $\mathrm{E}$ cell preparation and a different anti-E serum was used. In each case, pretreatment with the anti-E serum resulted in the development of resistance to lysis to the same antibody with complement. The treated cells remained fully susceptible to killing by antibodies directed at the A, B, and C, HLA alleles tested. The cytotoxicity readings of all the sera for a given specificity were strong and remained strong (75-100\% kill) indicating that the antigen was not affected by the stripping procedure. These assays involved five alleles of HLA-A, four alleles of HLA-B, and three alleles of HLA-C. In addition, each of these E cells were also typed for the antigens W4(4a) and W6(4b) using Sixth Workshop typing sera for each of these specificities. These sera were: $6 \mathrm{~W} 146$ and 147 for W4, and $6 \mathrm{~W} 148,149$, and 150 for W6. Reactions with all of them remained unchanged after anti-E resistanceinduction.

Presence of $E$ antigens in blood monocytes. Although the sera selected for these studies were not reactive with peripheral blood lymphocytes in direct

TABLE I

Effect of Absorption with E Cells and with Lymphocytes on Cytotoxic Reactions of Sera from Transplant Recipients

\begin{tabular}{|c|c|c|c|c|}
\hline \multirow[b]{2}{*}{ Specificity of sera studied } & \multirow[b]{2}{*}{$\begin{array}{l}\text { Cells used for } \\
\text { absorption* }\end{array}$} & \multicolumn{3}{|c|}{ Number of sera cytotoxic } \\
\hline & & $\begin{array}{c}\text { Before } \\
\text { absorp- } \\
\text { tion }\end{array}$ & $\begin{array}{l}\text { After } \\
\text { absorp- } \\
\text { tion }\end{array}$ & $\begin{array}{c}\text { Percent } \\
\text { absorbed }\end{array}$ \\
\hline \multirow{2}{*}{$\begin{array}{l}\text { Antibodies to } \\
\text { endothelial cells } \\
\text { only }\end{array}$} & $\begin{array}{l}\text { Endothelial } \\
\text { cells }\end{array}$ & 20 & $\mathbf{0}$ & 100 \\
\hline & Lymphocytes & 35 & 28 & 20 \\
\hline \multirow{2}{*}{$\begin{array}{l}\text { Antibodies to } \\
\text { endothelial cells } \\
\text { and lymphocytes }\end{array}$} & $\begin{array}{l}\text { Endothelial } \\
\text { cells }\end{array}$ & 5 & $\mathbf{0}$ & 100 \\
\hline & Lymphocytes & 7 & $\mathbf{0}$ & 100 \\
\hline
\end{tabular}

${ }^{*} 1 \mu \mathrm{l}$ of serum was incubated with $3-6 \times 10^{4} \mathrm{E}$ cells or $1-2 \times 10^{5}$ lymphocytes for $2 \mathrm{~h}$ at $22^{\circ} \mathrm{C}$.

$\ddagger$ Cytotoxicity tested with $\mathrm{E}$ cells. 
TABLE II

Molecular Independence of E Antigens from HLA-A, HLA-B, and HLA-C

\begin{tabular}{|c|c|c|c|c|c|c|c|c|}
\hline \multirow{4}{*}{$\begin{array}{c}\begin{array}{c}\text { Experiment } \\
\text { number }\end{array} \\
1\end{array}$} & \multirow[b]{3}{*}{ Pretreatment } & \multicolumn{7}{|c|}{ Results of cytotoxicity } \\
\hline & & \multirow[b]{2}{*}{ Anti-E } & \multicolumn{6}{|c|}{ Anti-HLA* } \\
\hline & & & \multicolumn{2}{|c|}{ A } & \multicolumn{2}{|c|}{ B } & \multicolumn{2}{|c|}{ C } \\
\hline & & $\mathbf{A M}$ & A2 & A9 & BW35 & & & \\
\hline & AB serum & 80 & + & + & + & & & \\
\hline & Serum AM & $<10$ & + & + & + & & & \\
\hline \multirow[t]{3}{*}{2} & & RD & Al & A2 & B5 & B27 & CW2 & CW3 \\
\hline & $A B$ serum & 75 & + & + & + & + & + & + \\
\hline & Serum RD & $<10$ & + & + & + & + & + & + \\
\hline \multirow[t]{3}{*}{3} & & $\mathrm{BM}$ & AW30 & & BW17 & BW35 & CW4 & \\
\hline & AB serum & 95 & + & & + & + & + & \\
\hline & Serum BM & $<10$ & + & & + & + & + & \\
\hline
\end{tabular}

* Sera used to identify HLA antigens had the following numbers in the 6th International Histocompatibility Workshop: A1, 001, 002; A2, 003, 004, 005; A9, 015, 016, 017; B5, 049, 050, 051, 053, 054; BW35, 055, 056, 057; B17, 091, 092, 093; B27, 107, 108, 109, 110; CW2, 155, 156, 157, 158, 159, 160, 161; CW3, 162, 163, 164, 165, 166, 167; CW4, 168, 169, 170, 171, 172, 173, 174 (see Histocompatibility Testing 1975 , reference 1).

cytotoxicity experiments, 7 out of 35 mononuclear cell preparations were able to absorb $\mathrm{E}$ antibodies. To investigate whether the relevant antigens were expressed in a subpopulation, cells obtained after FicollHypaque centrifugation were separated into adherent and nonadherent fractions by incubation in Petri dishes. E-specific sera were then tested with preparations of E cells, adherent monocytes, and nonadherent lymphocytes from each donor. Results of two such experiments are shown in Table III. The sera were cytotoxic for $\mathrm{E}$ cells and for blood monocytes. The nonadherent lymphocytes, by contrast, were unreactive.

Absorption of E antibodies with monocytes. Preincubation of anti-E sera with blood monocytes abolished the cytotoxicity for the corresponding $\mathrm{E}$ cells in every case in two separate experiments (Table IV). Unreactive monocytes did not absorb.

Absence of $E$ antigens in $B$ lymphocytes. 24 selected sera known to contain antibodies to $\mathrm{E}$ antigens were tested for reaction with $\mathrm{T}$ and $\mathrm{B}$ lymphocytes isolated from the cord blood of five newborn donors. At the same time, umbilical vein $\mathrm{E}$ cells and blood monocytes were also tested. As previously noted, the reactions with $\mathrm{E}$ cells and monocytes were concordant. $\mathrm{T}$ and $\mathrm{B}$ lymphocytes did not react with any of the selected sera. In addition to the anti-E sera, we also tested seven pregnancy sera and one rabbit serum known to react with Ia-like antigens of human B lymphocytes, as well as one rabbit serum specific for antigens of human $\mathrm{T}$ lymphocytes. The anti-Ia sera reacted with B lymphocytes, as expected, and also with $\mathrm{E}$ cells and monocytes. The reactions of serum P. J. were very strong, killing $90 \%$ of each of the three cell preparations. Serum J. B. killed $60 \%$ of the E cells and $50 \%$ of both the monocytes and the B lymphocytes. The heterologous anti-T lymphocyte serum killed $80 \%$ or more of the cells in the Tlymphocyte preparations but none of the other cells.

\section{DISCUSSION}

E cells were found to react with monospecific typing sera for alleles of HLA-A and B, as well as HLA-C when tested, in good agreement with the reactions of lymphocytes from the same donors. However, certain alloantisera obtained from kidney transplant recipients

TABLE III

Presence of $E$ Antigens in E Cells and in Adherent Cells from Peripheral Blood

\begin{tabular}{|c|c|c|c|}
\hline \multirow[b]{2}{*}{$\begin{array}{l}\text { Sera } \\
\text { tested }\end{array}$} & \multicolumn{3}{|c|}{ Results of cytotoxicity tests } \\
\hline & E cells & $\begin{array}{c}\text { Adherent } \\
\text { monocytes }\end{array}$ & $\begin{array}{l}\text { Nonadheren } \\
\text { lymphocytes }\end{array}$ \\
\hline & \multicolumn{3}{|c|}{$\%$ killed } \\
\hline \multicolumn{4}{|c|}{ Experiment 1} \\
\hline G. B. & 50 & 60 & $<10$ \\
\hline R. G. & 70 & 80 & $<10$ \\
\hline W. W. & 60 & 40 & $<10$ \\
\hline C. S. & 75 & 80 & $<10$ \\
\hline E. W. & 90 & 70 & $<10$ \\
\hline V. S. & 80 & 65 & $<10$ \\
\hline \multicolumn{4}{|c|}{ Experiment 2} \\
\hline J. W. & 60 & 40 & $<10$ \\
\hline E. W. & 50 & 30 & $<10$ \\
\hline R. G. & 60 & 50 & $<10$ \\
\hline G. B. & 60 & 80 & $<10$ \\
\hline B. Mc. & 40 & 10 & $<10$ \\
\hline
\end{tabular}


TABLE IV

Absorption of E Antibodies with Blood Monocytes

\begin{tabular}{|c|c|c|c|c|c|c|c|c|}
\hline \multirow[b]{3}{*}{ Sera tested } & \multicolumn{8}{|c|}{ Cytotoxicity to E cells } \\
\hline & \multicolumn{4}{|c|}{ Before absorption } & \multicolumn{4}{|c|}{ After absorption } \\
\hline & $1: 1$ & $1: 2$ & $1: 4$ & $1: 8$ & $1: 1$ & $1: 2$ & $1: 4$ & $1: 8$ \\
\hline \multicolumn{9}{|c|}{ Experiment 1} \\
\hline G. B. & 90 & 90 & 50 & 30 & 20 & 10 & $<10$ & $<10$ \\
\hline R. G. & 90 & 80 & 80 & 80 & 20 & $<10$ & $<10$ & $<10$ \\
\hline W. W. & 75 & 75 & 30 & $<10$ & $<10$ & $<10$ & $<10$ & $<10$ \\
\hline K. S. & 80 & 80 & 80 & 40 & 15 & $<10$ & $<10$ & $<10$ \\
\hline \multicolumn{9}{|c|}{ Experiment 2} \\
\hline F. T. & 80 & 75 & 50 & 40 & $<10$ & $<10$ & $<10$ & $<10$ \\
\hline R. W. & 70 & 45 & 20 & 10 & 10 & $<10$ & $<10$ & $<10$ \\
\hline B. L. & 90 & 80 & 40 & 40 & 10 & $<10$ & $<10$ & $<10$ \\
\hline
\end{tabular}

* For absorption, $6 \times 10^{4}$ monocytes were incubated with $1 \mu \mathrm{l}$ of serum for $2 \mathrm{~h}$ at room temperature before cytotoxicity testing.

were cytotoxic for $\mathrm{E}$ cells and not for the corresponding lymphocyte preparations (20). Out of 110 sera from 60 transplant recipients, 47 were cytotoxic for $\mathrm{E}$ cells only and not for lymphocytes. The extra reactions with E cells could not be attributed to an effect of trypsin since similar treatment of lymphocytes did not elicit extra reactions, and incubation of $\mathbf{E}$ cells in culture medium after trypsin treatment did not change their reactivity (20). It is known that certain antibodies may produce cytotoxicity-negative, absorption-positive reactions when, for one reason or other, the conditions required for cytolysis are not met. But the results of absorption experiments did not support this possibility. Only 7 out of 35 lymphocyte preparations inhibited the reactions of $E$ antibodies. Since the number of lymphocytes used for absorption was in excess of that usually required to inhibit anti-HLA antibodies, it appears that the amount of antigen present was small or perhaps was expressed in a subpopulation of cells, insufficient in most cases to remove the antibodies.

Antigen redistribution experiments were performed by the resistance-induction method $(27,28)$ to investigate whether $\mathrm{E}$ antigens are separate from the products of the HLA-A, B, and C loci. In these experiments, resistance to lysis developed after treatment with specific anti-E antibodies, but the treated $E$ cells remained susceptible to the cytotoxic effects of antiHLA-A, B, and C reagents. The concordant reactions of several typing sera of high quality is strong evidence that the HLA-A, B, and C antigens were not affected by the "stripping" procedure. Although it is not known whether resistance to cytolysis in such experiments is actually due to removal (stripping) of the molecules as in antigen redistribution observed by immunofluorescence, it is well established that the method has a high degree of specificity $(27,28)$. Thus, $E$ antigens appear to be distinct and most likely located in separate molecules on the surface of $E$ cells.

Because of the possibility that $\mathrm{E}$ antigens might be expressed in a subpopulation of cells from peripheral blood, mononuclear cells were separated into adherent and nonadherent cells by incubation in Petri dishes. The results of cytotoxicity tests showed that $\mathrm{E}$ antibodies did not react with lymphocytes but that cytotoxicity for monocytes and $\mathrm{E}$ cells was concordant in most cases. Moreover blood monocytes were able to absorb the $\mathrm{E}$ antibody reactions. These absorptions were possible only with reactive monocytes, indicating that the effect of the monocytes was antigen specific. Thus, it appears that $\mathrm{E}$ antigens are expressed in blood monocytes in addition to endothelium.

It is now well known that products of the HLA-D region responsible for strong stimulation in mixed lymphocyte cultures and the Ia-like molecules that are targets for cytotoxic antibodies are expressed preferentially in B lymphocytes and monocytes, and are not detectable by cytotoxicity or immunofluorescence in $T$ lymphocytes from human blood (3-5). Since E cells (18) and macrophages (29) stimulate allogeneic lymphocytes in cultures it seems likely that these cells also express HLA-D-region products. Thus, one could have assumed that the $\mathrm{E}$ antigens here described, were the same as the Ia-like determinants. The reactions observed with sera known to contain antibodies against Ia-like antigens of human B lymphocytes were in agreement with the possibility that Ia-like antigens exist in B lymphocytes, monocytes, and $\mathrm{E}$ cells. In contrast, sera selected because they were known to contain anti-E antibodies reacted with $\mathrm{E}$ cells and monocytes, but $B$ lymphocytes were negative. Since anti-Ia sera killed from 50 to $90 \%$ of the cells in B lymphocyte preparations, absence of reaction of anti-E sera was likely to be significant and suggested that $\mathrm{E}$ antigens and Ia-like alloantigens were not the same. In other experiments, ${ }^{2}$ it has been observed that anti-E antibodies were not absorbed by incubation with normal B-lymphocyte preparations or cultured Bcell lines. It is therefore unlikely that absence of reaction with B lymphocytes could be due to cytotoxicitynegative, absorption-positive reactions. Furthermore, in preliminary experiments, ${ }^{2}$ using the lysostrip technique, $E$ cells that developed resistance to E-antibodies remained susceptible to lysis by anti-Ia sera. It must be concluded, therefore, that $\mathrm{E}$ antigens are separate and distinct from the Ia-like antigens.

Using methods traditional in HLA serology, it has been possible to identify eight allelic $\mathrm{E}$ specificities (30). There was one triplet in a panel of 30 cells, suggesting that the specificities were controlled by a single genetic locus. If these antigens do play a role in kidney transplantation, matching of donors and recipients for $\mathbf{E}$ antigens and cross matching recipient

\footnotetext{
${ }^{2}$ Moraes, J. R., and P. Stastny. Unpublished observations.
} 
serum with donor monocytes would certainly be a possibility.

\section{ACKNOWLEDGMENT}

This work was supported in part by National Institutes of Health grant 5-RO1-AI12563-02.

\section{REFERENCES}

1. WHO-IUIS Terminology Committee. 1975. Nomenclature for factors of the HLA system. In Histocompatibility Testing 1975. F. Kissmeyer-Nielsen, editor. Munksgaard, Copenhagen, Denmark. 5-20.

2. Thorsby, E., and A. Piazza, editors. 1975. Joint report from the Sixth International Histocompatibility Workshop Conference. II. Typing for HLA-D (LD-1 or MLC) determinants. In Histocompatibility Testing 1975. F. Kissmeyer-Nielsen, editor. Munksgaard, Copenhagen, Denmark. 414-434.

3. Rood, J. J. van, A. van Leeuwen, J. J. Keuing, and A. Blussé van Oud Alblas. 1975. The serological recognition of the human MLC determinants using a modified cytotoxicity technique. Tissue Antigens. 5: 73-79.

4. Jones, E. A., P. N. Goodfellow, J. G. Bodmer, and W. F. Bodmer. 1975. Serological identification of HLA-linked human "Ia-type" antigens. Nature (Lond.). 256: 650-652.

5. Winchester, R. J., S. M. Fu, P. Wernet, H. G. Kunkel, B. Dupont, and C. Jersild. 1975. Recognition by pregnancy serums of non-HLA alloantigens selectively expressed on B lymphocytes. J. Exp. Med. 141: 924-929.

6. Allen, F. H., Jr. 1974. Linkage of HL-A and GBG. Vox Sang. 27: 382-384.

7. Fu, S. M., H. G. Kunkel, H. P. Brusman, F. H. Allen, Jr., and M. Fotino. 1974. Evidence for linkage between HL-A histocompatibility genes and those involved in the synthesis of the second component of complement. J. Exp. Med. 140: 1108-1111.

8. Rittner, C., G. Hauptmann, H. Grosse-Wilde, E. Grosshans, M. M. Tongio, and S. Mayer. 1975. Linkage between HL-A (major histocompatibility complex) and genes controlling the synthesis of the fourth component of complement. In Histocompatibility Testing 1975. F. Kissmeyer-Nielsen, editor. Munksgaard, Copenhagen, Denmark. 945-953.

9. Einstein, L. P., C. A. Alper, K. J. Bloch, J. T. Herrin, F. S. Rosen, J. R. David, and H. R. Colten. 1975. Biosynthetic defect in monocytes from human beings with genetic deficiency of the second component of complement. N. Engl. J. Med. 292: 1169-1171.

10. Dorf, M. E., H. Balner, and B. Benacerraf. 1975. Mapping of the immune response genes in the major histocompatibility complex of the rhesus monkey. J. Exp. Med. 142: 673-693.

11. Buckley, C. E., III, F. C. Dorsey, R. B. Corley, W. B. Ralph, M. A. Woodbury, and D. B. Amos. 1973. HL-A linked human immune-response genes. Proc. Natl. Acad. Sci. U. S. A. 70: 2157-2161.

12. Haverkorn, M. J., B. Hofman, N. Masurel, and J. J. van Rood. 1975. HL-A linked genetic control of immune response in man. Transplant Rev. 22: 120-124.
13. The 12th Report of the Human Renal Transplant Registry. 1975. JAMA (J. Am. Med. Assoc.). 233: 787-796.

14. Perkins, H. A., Z. Gantan, S. Siegel, E. Howell, F. O. Belzer, and S. L. Kountz. 1975. Reactions of kidney cells with cytotoxic antisera: possible evidence for kidneyspecific antigens. Tissue Antigens. 5: 88-98.

15. Jeannet, M., V. W. Pinn, M. H. Flax, H. J. Winn, and P. S. Russell. 1970. Humoral antibodies in renal allotransplantation in man. N. Engl. J. Med. 282: 111-117.

16. Festenstein, H., J. A. Sachs, A. M. I. Paris, G. D. Pegrum, and J. F. Moorhead. 1976. Influence of HLA matching and blood-transfusion on outcome of 502 London transplant group renal-graft recipients. Lancet. 1: 157-161.

17. Vetto, R. M., and D. R. Burger. 1971. The identification and comparison of transplantation antigens on canine vascular endothelium and lymphocytes. Transplantation (Baltimore). 11: 374-377.

18. Hirschberg, H., S. A. Evensen, T. Henriksen, and E. Thorsby. 1974. Stimulation of human lymphocytes by allogeneic endothelial cells in vitro. Tissue Antigens. 4: 257-261.

19. Busch, G. J., E. G. Galvanck, E. S. Reynolds, Jr. 1971. Human renal allografts. Analysis of lesions in long-term survivors. Hum. Pathol. 2: 253-298.

20. Moraes, J. R., and P. Stastny. 1975. Allo-antibodies to endothelial cell antigens. In Histocompatibility Testing 1975. F. Kissmeyer-Nielsen, editor. Munksgaard, Copenhagen, Denmark. 391-397.

21. Böyum, A. 1974. Separation of blood leucocytes, granulocytes and lymphocytes. Tissue Antigens. 4: 269-274.

22. Young, M. R., and A.V. Smith. 1964. The use of euchrysine in staining cells and tissues for fluorescence microscopy. J. R. Microsc. Soc. 82: 233-244.

23. Weiner, M. S., C. Bianco, and V. Nussenzweig. 1973. Enhanced binding of neuraminidase-treated sheep erythrocytes to human T lymphocytes. Blood. 42: 939-946.

24. Boyle, W. 1968. An extension of the ${ }^{51} \mathrm{Cr}$-release assay for the estimation of mouse cytotoxins. Transplantation (Baltimore). 6: 761-764.

25. Bodmer, W., M. Tripp, and J. Bodmer. 1967. Application of a fluorochromatic cytotoxicity assay to human leukocyte typing. In Histocompatibility Testing 1967. E. S. Curtoni, P. L. Mattiuz, and R. M. Tosi, editors. Munksgaard, Copenhagen, Denmark. 341-350.

26. Tourraine, J. L., F. Tourraine, D. F. Kiszkiss, Y. S. Choi, and R. A. Good. 1974. Hetorologous specific antiserum for identification of human T lymphocytes. Clin. Exp. Immunol. 16: 503-520.

27. Bernoco, O., S. Cullen, G. Scudeller, G. Trichieri, and R. Cepellini. 1973. HL-A molecules at the cell surface. In Histocompatibility Testing 1967. E. S. Curtoni, P. L. Mattuiz, and R. M. Tosi, editors. Munksgaard, Copenhagen, Denmark. 527-537.

28. Hauptfeld, V., M. Hauptfeld, and J. Klein. 1975. Induction of resistance to antibody-mediated cytotoxicity. H-2, Ia and Ig antigens are independent entities in the membrane of mouse lymphocytes. J. Exp. Med. 141: 10471056.

29. Schirrmacher, V., J. Pena-Martinez, and H. Festenstein. 1975. Specific lymphocyte-activating determinants expressed on mouse macrophages. Nature (Lond.). 255: $155-156$.

30. Moraes, J. R., and P. Stastny. 1976. Eight groups of human endothelial cell alloantigens. Tissue Antigens. 8: 273-276. 